Культуры in vitro

УДК 633.18:581.143.6

doi: 10.15389 /agrobiology.2019.3.557rus

\title{
СЕЗОННОСТЬ АНДРОГЕНЕТИЧЕСКИХ ОТВЕТОВ В КУЛЬТУРЕ ПЫЛЬНИКОВ РИСА (Oryza sativa L.) in vitro
}

\author{
М.В. ИЛЮШКО, М.В. РОМАШОВА
}

Условия выращивания растений-доноров в андрогенезе in vitro рассматриваются с позиции воздействия на растения физических факторов (освещенность, длина светового дня, температура, питание растений). Считается, что для культуры клеток и тканей in vitro подходит любой сезон, однако в отдельные периоды года культуры in vitro растут и развиваются лучше, чем в другие. Исследований, связанных с введением в культуру пыльников in vitro во все периоды года, мы не обнаружили. В настоящей работе впервые показано, что интенсивность каллусообразования и регенерации растений риса посевного (Oryza sativa L.) различается в зависимости от месяца введения пыльников в культуру in vitro при единообразных условиях выращивания растенийдоноров в течение года. Пониженная температура $21{ }^{\circ} \mathrm{C}$ позволяла получать каллус с разной интенсивностью в течение всего года, при оптимальной для риса температуре $24{ }^{\circ} \mathrm{C}$ наблюдалась большая сезонная зависимость. Нашей целью было изучение сезонной зависимости андрогенетических ответов in vitro риса при выращивании растений-доноров в контролируемых условиях климатической камеры при двух температурных режимах. В работе использовали пыльники риса подвида јаропica Каto сорта Каскад. Растения-доноры высаживали в грунт ежемесячно 15 числа по 5-9 растений в течение года и помещали в климатическую камеру при температурах 24 и $21{ }^{\circ} \mathrm{C}$, освещенности 15 тыс. лк, влажности $60 \%$, фотопериоде 14/10 ч (свет/темнота). Контролем служили пыльники с растений, выращенных на вегетационной площадке в естественных условиях. В контроле пыльники вводили в культуру in vitro в августе 2015 и 2016 года в количестве 400 шт. Перед введением в культуру пыльники риса подвергали воздействию низких положительных температур $\left(5^{\circ} \mathrm{C}\right)$ в течение 7 сут, помещая метелки в цилиндры с водой. Культивирование проводили на индукционной питательной среде $\mathrm{N}_{6}$. Число высаженных пыльников ежемесячно составляло от 400 до 702 шт. Максимальная частота каллусообразования приходилась на май-июнь $(15,5-28,3 \%)$. При выращивании растений-доноров в искусственных условиях при обеих температурах в этот период каллусообразование было выше, чем в контроле. Использование климакамеры позволяло получить в отдельные месяцы стабильно высокие значения интенсивности каллусообразвания, что не всегда возможно в естественных условиях выращивания исходных растений. Температура выращивания растений-доноров влияла на каллусообразование и регенерационную способность побегов из пыльников риса. Низкая для риса температура $\left(21{ }^{\circ} \mathrm{C}\right)$ позволяла получать каллус ежемесячно с большей или менышей интенсивностью (1,0-15,5\%). При оптимальной температуре $24{ }^{\circ} \mathrm{C}$ в ранневесенний и позднеосенний периоды образования каллуса из пыльников не наблюдалось. При температуре выращивания растений-доноров $21{ }^{\circ} \mathrm{C}$ формировалось в 4 раза болыше каллусов с зелеными регенерантами $(31,6 \%)$ по сравнению с температурой $24{ }^{\circ} \mathrm{C}(8,8 \%)$, увеличивалась доля удвоенных гаплоидов до $28,1 \%$ и их среднее число на каллус до 16,6 шт. Выявлена средняя корреляционная зависимость между долей каллусов с зелеными регенерантами и средним числом удвоенных гаплоидов на каллус $(r=0,59$ при $\mathbf{p}=\mathbf{0 , 0 5}$ ). Это означает, что с увеличением числа каллусов с зелеными регенерантами, которое наблюдалось при $21{ }^{\circ} \mathrm{C}$, возрастал общий выход удвоенных гаплоидов. По числу гаплоидов такой зависимости не отмечали. Таким образом, вполне оправдано применение закрытых помещений (теплиц, климакамер) не только в целях создания регулируемых условий для выращивания растений-доноров, что часто практикуется исследователями, но и для использования наиболее благоприятного периода введения пыльников в культуру in vitro.

Ключевые слова: Oryza sativa L., андрогенез in vitro, каллусообразование, регенерация, удвоенные гаплоиды, сезонность.

Культура пыльников риса in vitro применяется для генетических исследований и селекционных целей с 1968 года (1). Работы по получению удвоенных гаплоидов риса успешно проводятся на протяжении пяти десятилетий, однако выведение новых сортов, гибридов и линий требует оптимизации условий культивирования пыльников, поскольку известна значительная зависимость каллусообразования и регенерации от генотипа исходного растения. Она считается ключевой проблемой в андрогенезе растений in vitro, в том числе у риса (2-4). Тем не менее существует и ряд 
других факторов, влияющих на процесс андрогенеза: условия выращивания растений-доноров, шоковая обработка пыльников перед введением в культуру in vitro, составы питательных сред, условия культивирования пыльников и каллусов (5-7).

Условия выращивания растений-доноров рассматриваются с позиции воздействия на них физических факторов (освещенность, длина светового дня, температура, питание растений) $(5,8)$. Считается, что для культуры клеток и тканей растений in vitro подходит любой период года (сезон), в чем и заключается ведущее преимущество этой технологии по сравнению с традиционным сельскохозяйственным производством (9). Однако опытные исследователи знают, что культуры in vitro в отдельные периоды года растут и развиваются лучше, чем в другие. Стали появляться немногочисленные экспериментальные сведения о сезонности развития растений в условиях in vitro. Так, черенкование Sequoiadendron giganteum (Lindl.) J. Buchholz весной (март-май) способствует более длительному сохранению большего числа живых черенков (10). У розы эфиромасличной, выращенной в предгорной зоне Крыма, летний период был наиболее благоприятным. Число развивающихся эксплантов у пяти сортов в это время достигло 92-97 \%, осенью показатель был минимальным - 40-72 \% (11). У розы на южном берегу Крыма лучшими сроками отбора и введения экспланта в культуру были февраль-март, когда частота развития меристем достигала 92-100 \%, в осенне-летний период этот показатель не превышал 10-20\% (12). Авторы заключают, что такая морфогенетическая реакция обусловлена физиологическим состоянием органа растения и выделяемого из него экспланта (12). Исследований, связанных с введением пыльников в культуру in vitro во все периоды года, мы не обнаружили. Сезонность рассматривается исключительно при сравнении растений-доноров, выращенных в полевых условиях и в закрытых помещениях.

Некоторые исследователи круглогодично вводят пыльники in vitro без стабильного результата, но в большинстве случаев культивирование стараются приурочить к концу весны. Существует множество сообщений об использовании теплиц и климакамер, в которых выращивают растениядоноры для культуры пыльников риса $(13,14)$. Главное преимущество использования закрытых помещений - возможность регулирования условий выращивания $(5,6)$ и асептическая чистота вводимых в культуру пыльников $(5,15)$. Во всех этих работах акцент делается на условия выращивания исходных растений, а не на сезонность.

В проблематике условий выращивания растений-доноров также нет однозначного ответа, как получить максимальный выход удвоенных гаплоидов. Исследователи едины во мнении, что для разных видов, родов и семейств условия должны быть неодинаковыми $(4,16)$. Для риса в большинстве случаев стараются создать максимально благоприятные условия для роста и развития исходных растений $(2,6)$ как в поле $(17-19)$, так и в закрытых помещениях $(13,14)$.

Есть отдельные свидетельства, что стрессовые условия выращивания исходных растений благоприятно влияют на процессы каллусообразования или регенерации побегов. У риса, растущего в сухой сезон, больше микроспор в пыльниках, способных к андрогенетическим ответам (6). У растений, выращенных при 18-20 ${ }^{\circ} \mathrm{C}$, в сравнении с выращиванием при 26-28 ${ }^{\circ} \mathrm{C}$ частота получения каллусов и регенерация зеленых побегов были более чем в 2 раза выше, а образование альбиносов - ниже (цит. по 20). Частота формирования зеленых регенерантов оказалась выше при выращивании растений-доноров в культуральной комнате при $20{ }^{\circ} \mathrm{C}$, чем на 
вегетационной площадке (21). Все эти экспериментальные данные также получены в отрыве от сезонной зависимости.

В настоящем исследовании впервые показано, что интенсивность каллусообразования и регенерации растений риса посевного различается в зависимости от месяца введения пыльников в культуру in vitro при единообразных условиях выращивания растений-доноров в течение года. Наиболее благоприятным периодом для введения пыльников в условия in vitro были май-июнь. Пониженная температура $21{ }^{\circ} \mathrm{C}$ позволяла получать каллус с разной интенсивностью в течение всего года, при оптимальной для риса температуре $24^{\circ} \mathrm{C}$ наблюдалась большая сезонная зависимость.

Целью работы было изучение сезонной зависимости андрогенетических ответов риса Oryza sativa L. при выращивании растений-доноров в контролируемых условиях климатической камеры in vitro при двух температурных режимах.

Методика. Опыты проводили в ФНЦ агробиотехнологий Дальнего Востока им. А.К. Чайки. В работе использовали пыльники риса O. sativa подвида japonica Kato сорта Каскад. Растения-доноры высаживали в грунт по 5-9 шт. ежемесячно 15 числа в течение года и помещали в климатическую камеру MLR-352H («Sanyo», Япония) при следующих условиях: температура 24 и $21{ }^{\circ} \mathrm{C}$, освещенность 15 тыс. лк, влажность $60 \%$, фотопериод (свет/темнота) 14/10 ч. Эксперимент с температурой $24{ }^{\circ} \mathrm{C}$ закладывали в 2015 году, с температурой $21^{\circ} \mathrm{C}$ - в 2016 году. Контролем служил вариант выращивания растений-доноров на вегетационной площадке в сосудах. В контроле пыльники (400 шт.) вводили в культуру in vitro в августе 2015 и 2016 годов.

Перед введением в культуру пыльники риса подвергали воздействию низких положительных температур $\left(5^{\circ} \mathrm{C}\right)$ в течение 7 сут, помещая метелки в цилиндры с водой. Культивирование проводили на индукционной питательной среде $\mathrm{N}_{6}(22)$. Число высаженных пыльников ежемесячно составляло от 400 до 702 шт.

Пыльники культивировали в темноте при температуре $25-27{ }^{\circ} \mathrm{C}$ до образования каллуса размером 1-5 мм. Затем его переносили на среду $\mathrm{N}_{6}$-рк (23) для регенерации побегов. Условия культивирования каллусов в культуральной комнате: освещенность 4 тыс. лк, температура 22-25 ${ }^{\circ} \mathrm{C}$, фотопериод 16/8 ч. Для укоренения регенерантов использовали среду MS (24) с половинным минеральным составом макросолей в вариации, приведенной Ю.К. Гончаровой (20).

Регенеранты с развитой корневой системой высаживали в горшечную культуру и продолжали выращивать в условиях культуральной комнаты до образования семян. По морфологическим признакам все растениярегенеранты разделили на группы: гаплоиды (без семян с очень мелкими цветками); удвоенные гаплоиды (с семенами); тетраплоиды (с очень крупными немногочисленными семенами, выраженным килем и ребристостью на цветочной чешуе); растения без семян (сформировали цветки нормального размера, но не образовали семян на двух и более метелках); растения, погибшие на ранних этапах роста и развития.

Статистическую обработку полученных данных проводили в программе Statistica 10 («StatSoft Inc.», США). Определяли среднее значение признака $(M)$, стандартное отклонение $( \pm \mathrm{SEM})$, коэффициент корреляции $(r)$. Разницу между вариантами оценивали с помощью $t$-критерия Стьюдента при уровне значимости не менее $5 \%$.

Результаты. При температуре выращивания растений-доноров $24{ }^{\circ} \mathrm{C}$ в культуру было введено 5172 пыльника, при $21{ }^{\circ} \mathrm{C}-7278$ пыльников 
(всего 12450 шт.). Сезонная зависимость наблюдалась при обеих температурах выращивания исходных растений, максимум частоты каллусообразования приходился на май при температуре $24{ }^{\circ} \mathrm{C}$ (рис. 1, А) и на май-июнь при $21{ }^{\circ} \mathrm{C}$ (см. рис. 1, Б). Однако низкая для риса температура позволяла получать каллус ежемесячно с большей или меньшей интенсивностью (1,0-15,5\%). При оптимальной температуре $24{ }^{\circ} \mathrm{C}$ в ранневесенний и позднеосенний периоды образования каллуса из пыльников не наблюдалось. Среднее значение каллусообразования по месяцам при температуре $24{ }^{\circ} \mathrm{C}$ составляло 4,5\%, при $21^{\circ} \mathrm{C}-3,9 \%$ (различия статистически не достоверны).

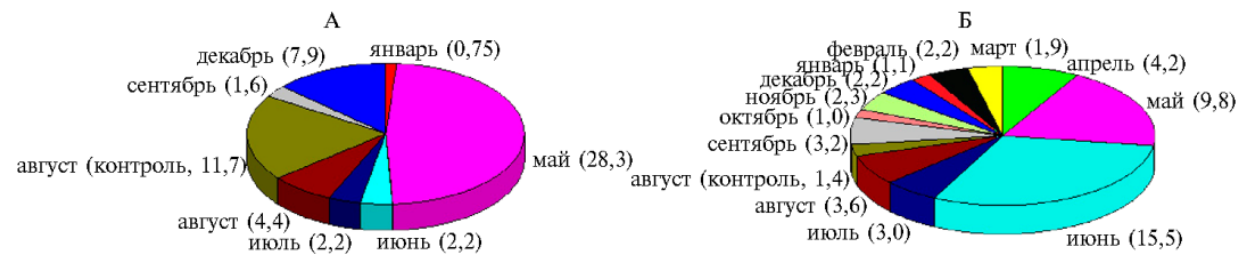

Рис. 1. Каллусообразование (\%) у риса (Oryza sativa spp. јароnica) сорта Каскад в зависимости от месяца введения пыльников в культуру in vitro и температуры выращивания растенийдоноров: А $-24{ }^{\circ} \mathrm{C}, \mathrm{Б}-21^{\circ} \mathrm{C}$.

1. Доля каллусов риса (Oryza sativa spp. japonica) сорта Каскад с зелеными регенерантами и альбиносами в зависимости от месяца введения пыльников в культуру in vitro и температуры выращивания растений-доноров

\begin{tabular}{|c|c|c|c|}
\hline \multirow{2}{*}{ Месяц } & \multicolumn{2}{|c|}{ Доля каллусов, \% } & \multirow{2}{*}{$\begin{array}{l}\text { Соотношение зеленые } \\
\text { регенеранты/альбиносы }\end{array}$} \\
\hline & с зелеными регенерантами & с альбиносами & \\
\hline \multicolumn{4}{|c|}{ Темп ератур а $24^{\circ} \mathrm{C}$} \\
\hline Май & 13,7 & 37,1 & 3,5 \\
\hline Июнь & 7,7 & 23,1 & 20,5 \\
\hline Июль & 5,9 & 26,5 & 0,8 \\
\hline Август (контроль) & 12,8 & 25,5 & 1,3 \\
\hline Август & 5,6 & 16,7 & 0,9 \\
\hline Сентябрь & 0 & 33,3 & 0 \\
\hline Декабрь & 15,9 & 15,9 & 24,3 \\
\hline Среднее $(M \pm \mathrm{SEM})$ & $8,8 \pm 2,1$ & $25,4 \pm 3,0$ & $7,3 \pm 3,9$ \\
\hline \multicolumn{4}{|c|}{ Темпе ратура $21^{\circ} \mathrm{C}$} \\
\hline Январь & 33,3 & 16,7 & 20,0 \\
\hline Февраль & 21,4 & 21,4 & 23,7 \\
\hline Март & 50,0 & 16,7 & 18,3 \\
\hline Апрель & 20,0 & 20,0 & 7,6 \\
\hline Май & 33,3 & 22,2 & 18,4 \\
\hline Июнь & 56,3 & 59,8 & 5,4 \\
\hline Июль & 23,1 & 7,7 & 9,8 \\
\hline Август & 33,3 & 52,4 & 2,3 \\
\hline Август (контроль) & 0 & 40,0 & 0 \\
\hline Сентябрь & 22,2 & 38,9 & 8,0 \\
\hline Октябрь & 60,0 & 20,0 & 44,0 \\
\hline Ноябрь & 50,0 & 16,7 & 21,1 \\
\hline Декабрь & 20,0 & 26,7 & 50,0 \\
\hline Среднее $(M \pm \mathrm{SEM})$ & $31,6 \pm 5,0$ & $27,6 \pm 4,3$ & $17,6 \pm 4,2$ \\
\hline При м еч ан и е. Ср & $\begin{array}{l}\text { ге значения }(M) \text { доли каллусов } \\
\text { ются при } \mathrm{p}=0,01 .\end{array}$ & зелеными регенер & нтами при 24 и $21^{\circ} \mathrm{C}$ стати- \\
\hline
\end{tabular}

Значения частоты каллусообразования в контроле в 2015 и 2016 годах различествовали. Так, условия 2015 года были типичными для роста и развития исходных растений, что привело к высокой частоте каллусообразования $(11,7$ \%) (см. рис. 1, А). В 2016 году сбор метелок пришелся на жаркий период, что могло повлиять как негативный стрессор на интенсивность каллусообразования, которое составило 1,4\% (см. рис. 1, Б), и привело к полному отсутствию регенерации побегов. При выращивании растений-доноров в искусственных условиях при обеих температурах в лучший период введения пыльников в культуру in vitro (май-июнь) каллу- 
сообразование было выше, чем в контроле. То есть использование климакамеры позволило получить в отдельные месяцы стабильно высокое каллусообразвание, что не всегда возможно в естественных условиях выращивания исходных растений.

При температуре выращивания исходных растений $24{ }^{\circ} \mathrm{C}$ в среднем было получено 8,8 \% каллусов с зелеными регенерантами, а при температуре $21{ }^{\circ} \mathrm{C}$ этот показатель достоверно $(t=3,35$ при $\mathrm{p}=0,004)$ увеличился в 4 раза и составил 31,6 \% (табл. 1). Следовательно, низкая для риса температура повлияла не только на расширение периода каллусообразования в течение года, но и на частоту образования каллусов с морфогенетическими ответами. Наметилась тенденция к уменьшению альбинизма в 2 раза. Интересно отметить, что при других способах увеличения регенерационной способности побегов из пыльников, например при подборе среды для регенерации из каллуса, также увеличивается число зеленых регенерантов за счет большего выхода каллусов, способных к морфогенетическим ответам (23).

Альбинизм рассматривается как проблема при получении растений-регенерантов у зерновых культур $(4,6)$. В нашей работе доля альбиносов была в несколько раз меньше, чем зеленых регенерантов (см. табл. 1), формировались они только на начальном этапе морфогенеза и легко удалялись с каллуса. Последующий пассаж каллусных агрегатов с зелеными инициалями позволял нормально развиться десяткам и сотням зеленых регенерантов.

2. Среднее число зеленых регенерантов на каллус в зависимости от месяца введения пыльников риса (Oryza sativa spp. japonica) сорта Каскад в культуру in vitro $(M \pm \mathrm{SEM})$

\begin{tabular}{|c|c|c|c|c|c|c|}
\hline \multirow[b]{2}{*}{ Месяц } & \multicolumn{6}{|c|}{ Число, шт. } \\
\hline & каллусов & гаплоидов & $\begin{array}{l}\text { удвоенных } \\
\text { гаплоидов }\end{array}$ & тетраплоидов & $\begin{array}{l}\text { погибших } \\
\text { растений }\end{array}$ & $\begin{array}{l}\text { растений } \\
\text { без семян }\end{array}$ \\
\hline \multicolumn{7}{|c|}{ Температура $24^{\circ} \mathrm{C}$} \\
\hline Май & 17 & $54,1 \pm 13,3$ & $14,8 \pm 3,9$ & 0 & $11,2 \pm 3,5$ & $0,3 \pm 0,2$ \\
\hline Июнь & 1 & 157 & 4 & 0 & 44 & 0 \\
\hline Июль & 2 & $16,0 \pm 10,0$ & $13,5 \pm 9,5$ & 0 & $2,5 \pm 1,5$ & 0 \\
\hline Август (контроль) & 6 & $17,2 \pm 15,4$ & $3,7 \pm 1,8$ & 0 & $1,7 \pm 0,8$ & 0 \\
\hline Август & 1 & 14 & 0 & 0 & 1 & 0 \\
\hline Декабрь & 7 & $54,9 \pm 24,4$ & $28,0 \pm 11,3$ & $1,6 \pm 1,6$ & $11,1 \pm 8,9$ & $1,4 \pm 0,8$ \\
\hline Среднее & $5,7 \pm 2,5$ & $10,9 \pm 5,6$ & $4,6 \pm 2,4$ & $0,3 \pm 0,3$ & $11,9 \pm 6,7$ & $0,3 \pm 0,2$ \\
\hline \multicolumn{7}{|c|}{ Температура $21^{\circ} \mathrm{C}$} \\
\hline Январь & 2 & $90,5 \pm 0,5$ & $1,0 \pm 0,0$ & 0 & $8,5 \pm 0,5$ & 0 \\
\hline Февраль & 3 & $33,0 \pm 31,5$ & $28,3 \pm 27,3$ & $0,3 \pm 0,3$ & $9,7 \pm 2,9$ & $4,3 \pm 4,3$ \\
\hline Март & 6 & $17,3 \pm 9,4$ & $23,5 \pm 17,9$ & 0 & $14,2 \pm 7,8$ & 0 \\
\hline Апрель & 5 & $27,4 \pm 13,3$ & $9,6 \pm 5,6$ & 0 & $9,8 \pm 7,2$ & $0,2 \pm 0,2$ \\
\hline Май & 17 & $31,9 \pm 8,4$ & $19,7 \pm 6,9$ & $0,5 \pm 0,5$ & $5,4 \pm 1,0$ & $1,9 \pm 1,2$ \\
\hline Июнь & 52 & $28,0 \pm 5,4$ & $10,9 \pm 2,5$ & $0,3 \pm 0,3$ & $8,9 \pm 1,4$ & $2,4 \pm 0,6$ \\
\hline Июль & 3 & $3,7 \pm 2,0$ & $9,7 \pm 7,3$ & 0 & $3,0 \pm 2,1$ & 0 \\
\hline Август (контроль) & 7 & $21,3 \pm 13,4$ & $5,9 \pm 2,4$ & 0 & $4,1 \pm 1,8$ & $1,4 \pm 1,0$ \\
\hline Сентябрь & 4 & $34,0 \pm 21,1$ & $18,5 \pm 11,2$ & 0 & $9,8 \pm 1,4$ & $1,0 \pm 0,6$ \\
\hline Октябрь & 3 & $3,3 \pm 1,3$ & $61,7 \pm 30,9$ & 0 & $7,0 \pm 3,4$ & $1,3 \pm 0,7$ \\
\hline Ноябрь & 6 & $12,0 \pm 5,7$ & $12,3 \pm 7,0$ & 0 & $3,3 \pm 3,3$ & $0,8 \pm 0,4$ \\
\hline Декабрь & 3 & $51,7 \pm 24,1$ & $15,0 \pm 10,0$ & 0 & $15,0 \pm 9,0$ & 0 \\
\hline Среднее & $9,3 \pm 4,1$ & $27,2 \pm 6,7$ & $16,6 \pm 4,3$ & $0,1 \pm 0,1$ & $8,2 \pm 1,1$ & $1,1 \pm 0,4$ \\
\hline
\end{tabular}

Среднее число регенерантов разного типа на каллус в зависимости от температуры выращивания исходных растений приведено в таблице 2. Статистически значимых различий по группам гаплоидов и удвоенных гаплоидов между месяцами в основном не отмечали, лишь между средними значениями удвоенных гаплоидов в июне и октябре при темпера- 
туре выращивания растений-доноров $21{ }^{\circ} \mathrm{C}$ наблюдалась достоверная разница $(t=4,26$ при $\mathrm{p}=0,0001)$. По среднему значению, рассчитанному для температур 24 и $21{ }^{\circ} \mathrm{C}$, были выявлены различия $(t=2,39$ при $\mathrm{p}=0,05)$ для удвоенных гаплоидов (см. табл. 2). Существовала средняя корреляционная зависимость между долей каллусов с зелеными регенерантами и средним числом удвоенных гаплоидов на каллус $(r=0,59$ при р $=0,05)$. Это означает, что с увеличением числа каллусов с зелеными регенерантами, которое наблюдалось при $21{ }^{\circ} \mathrm{C}$, возрастал общий выход удвоенных гаплоидов. По числу гаплоидов такой зависимости не обнаружили.

Общий объем полученных регенерантов составил 2464 и 5798 растений при температурах выращивания растений-доноров соответственно 24 и $21{ }^{\circ} \mathrm{C}$. Максимальное число регенерантов получили в мае-июне в соответствии с интенсивностью каллусообразования (рис. 2). При температуре $24{ }^{\circ} \mathrm{C}$ наблюдается небольшое повышение регенерационной способности в декабре.
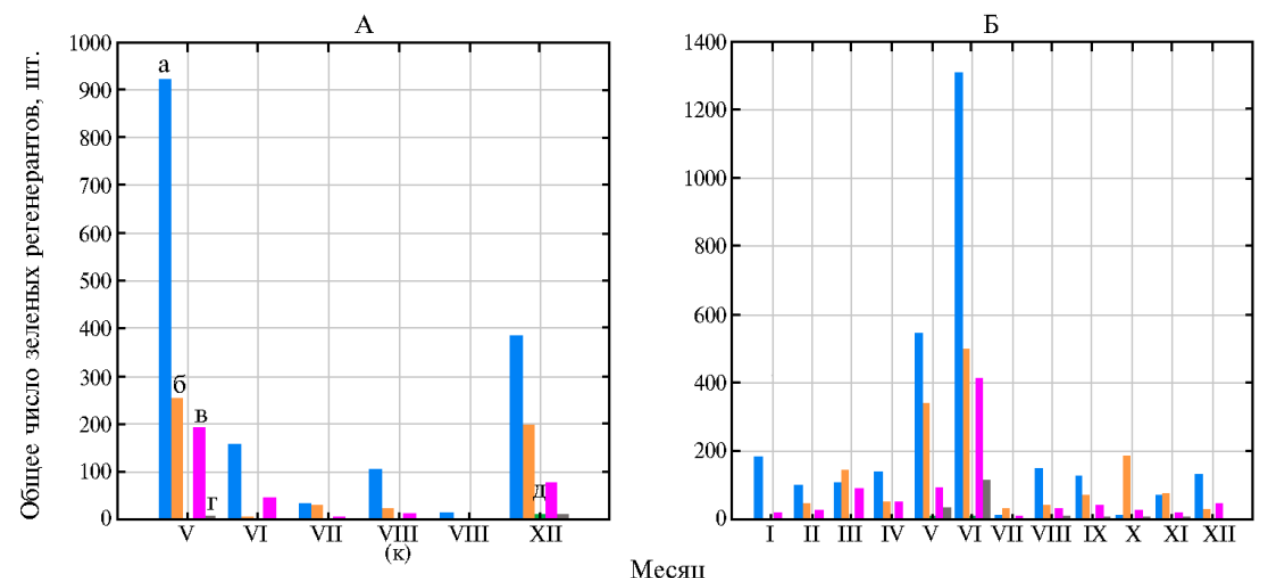

Рис. 2. Регенерация из каллуса в зависимости от месяца введения пыльников риса (Oryza sativa spp. japonica) сорта Каскад в культуру in vitro при температуре выращивания растений-доноров $24^{\circ} \mathbf{C}$ (А) и $21^{\circ} \mathbf{C}$ (Б): а - гаплоиды, б - удвоенные гаплоиды, в - погибшие растения, г растения без семян, д - тетраплоиды.

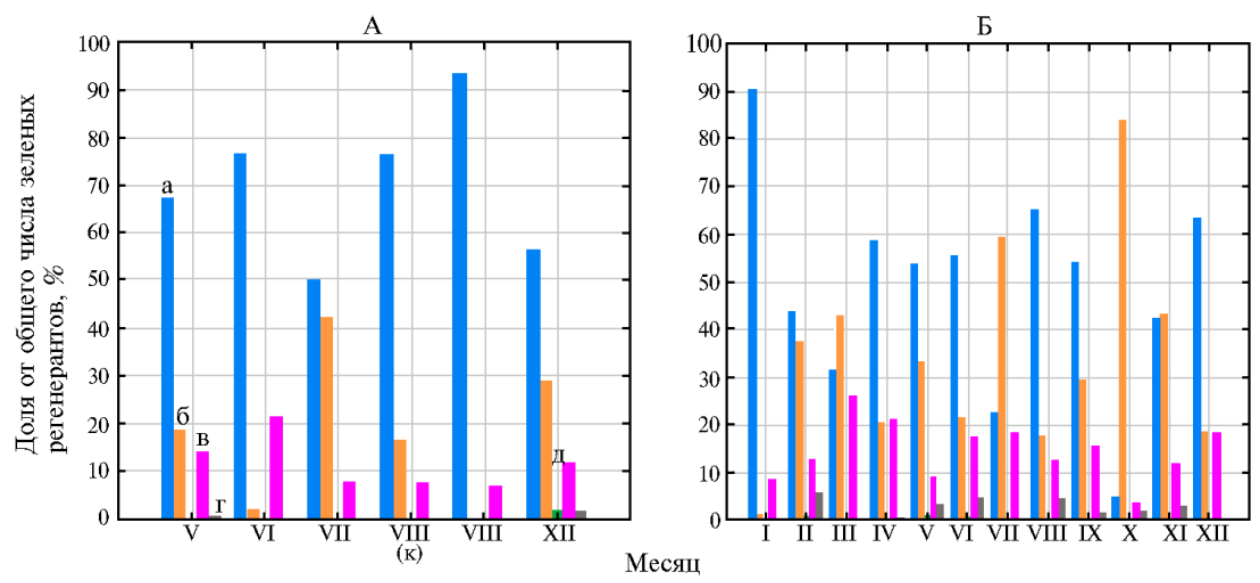

Рис. 3. Распределение регенерантов по группам в зависимости от месяца введения пыльников риса (Oryza sativa spp. јаропica) сорта Каскад в культуру in vitro при температуре выращивания растений-доноров $24^{\circ} \mathrm{C}$ (А) и $21^{\circ} \mathrm{C}$ (Б): а - гаплоиды, б - удвоенные гаплоиды, в - погибшие растения, г - растения без семян, д - тетраплоиды.

Доля регенерантов разного типа была неодинаковой в вариантах с 
разной температурой выращивания растений-доноров. Так, при $24{ }^{\circ} \mathrm{C}$ всегда преобладали гаплоидные растения, их доля за год исследований составила 65,3 \% и варьировала по месяцам от 50,0 до 93,3 \% (см. рис. 3, А). Доля удвоенных гаплоидов в среднем за год составила 20,3\%, варьирование по месяцам - от 0 до 42,2 \%. При $21^{\circ} \mathrm{C}$ в среднем за год получили $52,6 \%$ гаплоидов (варьирование от 4,6 до 90,5\%) и $28,1 \%$ удвоенных гаплоидов (от 1,0 до 84,1 \%) (см. рис. 3, Б). То есть при снижении температуры выращивания исходных растений в климатической камере наблюдалось увеличение доли удвоенных гаплоидов из полученных зеленых регенерантов. Это происходило за счет увеличения среднего числа регенерантов с каллуса. При использовании низкой для риса температуры в отдельные месяцы (март, июль, октябрь, ноябрь) доля удвоенных гаплоидов преобладала над долей гаплоидных растений (см. рис. 3).

Никакой зависимости в группах нежизнеспособных регенерантов, тетраплоидов и стерильных растений негаплоидного происхождения в эксперименте обнаружено не было, период года и температуры выращивания исходных растений не оказывали влияния на частоту их появления. Видимо, их формирование в каллусе имело спонтанный характер.

Выявленная сезонная зависимость андрогенетических ответов у риса хорошо согласуется с общебиологическими законами. Весна и начало лета - наиболее благоприятный период для активного прорастания семян и вегетативного размножения растений. Очевидно, что даже в искусственных условиях выращивания именно в этот период интенсифицируются каллусообразование и регенерация в культуре пыльников in vitro. Черенкование других растений в культуре in vitro также наиболее успешно весной (10-12). Вполне оправдано использование закрытых помещений (теплиц, климакамер) не только в целях создания регулируемых условий для вырашивания растений-доноров, что часто практикуется исследователями $(5,6)$, но и для использования благоприятного периода введения пыльников в культуру in vitro. Л.А. Першина с соавт. (25) отмечают негативную реакцию некоторых сортов пшеницы в культуре пыльников in vitro при выращивании растений-доноров в теплице. Возможно, с учетом сезонной зависимости андрогенетических ответов, результат мог стать другим.

Низкая температура при выращивании растений-доноров $\left(21{ }^{\circ} \mathrm{C}\right)$ служила дополнительным стрессором, который стимулировал андрогенетические ответы риса и позволил получать регенеранты в течение всего года, в то время как при более благоприятной температуре $\left(24{ }^{\circ} \mathrm{C}\right)$ это было возможно лишь в отдельные месяцы. Для переключения программы развития микроспоры зерновых с гаметофитного пути на спорофитный используются шоковые температуры (4-12 $\left.{ }^{\circ} \mathrm{C}\right)$ предобработки пыльников $(2,5,7)$. Предельно низкая для риса температура выращивания растенийдоноров дополняет и усиливает этот эффект. Ряд исследований показывают, что нет необходимости создавать лучшие условия для роста и развития растений-доноров, как принято считать. Стресс, в том числе температурный, усиливает каллусообразование и регенерацию (цит. по 20, 21).

Таким образом, существует сезонная зависимость каллусообразования в культуре пыльников риса in vitro. Максимальная частота каллусообразования приходится на май-июнь. Температура выращивания растений-доноров влияет на интенсивность каллусообразования и регенерационную способность побегов из пыльников. Пониженная для риса температура $21{ }^{\circ} \mathrm{C}$ позволяет получать каллус с разной интенсивностью в течение всего года, при оптимальной для риса температуре $24{ }^{\circ} \mathrm{C}$ каллусообразование возможно в периоды с мая по сентябрь и в декабре, январе. 
При температуре выращивания растений-доноров $21^{\circ} \mathrm{C}$ из пыльников формируется практически в 4 раза больше каллусов с зелеными регенерантами $(31,6 \%)$ по сравнению с температурой $24{ }^{\circ} \mathrm{C}(8,8 \%)$, доля удвоенных гаплоидов увеличивается до $28,1 \%$, их среднее число на каллус до 16,6 шт.

\section{ЛИТЕРАТУРА}

1. Niizeki B.H., Oono K. Induction of haploid rice plant from anther culture. Proceedings of the Japan Academy, 1968, 44(6): 554-557 (doi: 10.2183/pjab1945.44.554).

2. Mishra R., Rao G.J.N. In-vitro androgenesis in rice: advantages, constraints and future prospects. Rice Science, 2016, 23(2): 57-68 (doi: 10.1016/j.rsci.2016.02.001).

3. Xu L., Najeeb U., Tang G.X., Gu H.H., Zhang G.Q., He Y., Zhou W.J. Haploid and doubled haploid technology. In: Advances in Botanical Research-Rapeseed Breeding /S.K. Gupta, M. Delseny, J.-C. Kader (eds.). Academic Press, London, 2007: 181-216 (doi: 10.1016/S00652296(07)45007-8).

4. Dunwell J.M. Haploids in flowering plants: origins and exploitation. Plant Biotechnology Journal, 2010, 8(4): 377-424 (doi: 10.1111/j.1467-7652.2009.00498.x).

5. Ferrie A.M., Caswell K.L. Isolated microspore culture techniques and recent progress for haploid and doubled haploid plant production. Plant Cell Tiss. Organ Cult., 2011, 104(3): 301-309 (doi: 10.1007/s11240-010-9800-y).

6. Datta S.K. Androgenic haploids: factors controlling development and its application in crop improvement. Current Science, 2005, 89(11): 1870-1878.

7. Germanà M.A. Anther culture for haploid and double haploid production. Plant Cell Organ. Cult., 2011, 104(3): 283-300 (doi: 10.1007/s11240-010-9852-z).

8. Болвелл Г.П., Вуд К.Р., Гонзалес Р.А. и др. Биотехнология растений: культура клеток /Пер. с англ. В.И. Негрука; с предисл. Р.Г. Бутенко. М., 1989.

9. Уразалиев К.Р. Культуры клеток и тканей высших растений - перспективный источник ценных химических соединений. Биотехнология. Теория и практика, 2016, 2: 4-19.

10. Султонова М.С., Нимаджанова К. Влияние сроков черенкования и регуляторов роста на жизнеспособность черенков Sequoadendron giganteum (Lindl.) J. Buchholz в условиях in vitro. Инновации и продовольственная безопасность, 2014, 4: 77-81.

11. Егорова Н.А., Ставцева И.В. Микроразмножение сортов эфиромасличной розы в культуре in vitro. Вестник Удмуртского университета, 2016, 26(2): 45-52.

12. Митрофанова И.В., Митрофанова О.В., Браилко В.А., Лесникова-Седошенко Н.П. Биотехнологические и физиологические особенности культивирования in vitro ценных генотипов розы эфиромасличной. Известия ВУЗов. Прикладная химия и биотехнология, 2015, 2(13): 37-48.

13. Bishnoi U.S., Jain R.K., Gupta K.R., Chowdhury V.K., Chowdhury J.B. High frequency androgenesis in indica $\times$ Basmati rice hybrids using liquid culture media. Plant Cell, Tissue and Organ Culture, 2000, 61(2): 153-159 (doi: 10.1023/A:1006407912576).

14. Lapitan V.C., Redoña E.D., Abe T., Brar D.S. Molecular characterization and agronomic performance of $\mathrm{DH}$ lines from the $\mathrm{F}_{1}$ of indica and japonica cultivars of rice (Oryza sativa L.). Field Crop Research, 2009, 112(2-3): 222-228 (doi: 10.1016/j.fcr.2009.03.008).

15. Илюшко М.В. Применение феноксиуксусной кислоты в культуре пыльников риса in vitro. Вестник КрасГАУ, 2014, 6: 143-148.

16. Smýkal P. Pollen embryogenesis - the stress mediated switch from gametophytic to sporophytic development. Current status and future prospects. Biologia Plantarum, 2000, 43(4): 481-489 (doi: 10.1023/A:1002835330799).

17. Rout P., Naik N., Ngangkham U., Verma R.L., Katara J.L., Singh O.N., Samantaray S. Doubled haploids generated through anther culture from an elite long duration rice hybrid, CRHR32: method optimization and molecular characterization. Plant Biotechnology, 2016, 33: 177-186 (doi: 10.5511/plantbiotechnology.16.0719a).

18. Premvaranon P., Vearasilp S., Thanapornpoonpong S., Karladee D., Gorinstein S. In vitro studies to produce double haploid in Indica hybrid rice. Biologia, 2011, 66(6): 1074-1081 (doi: 10.2478/s11756-011-0129-8).

19. Mishra R., Rao G.J.N., Rao R.N., Kaushal P. Development and characterization of elite doubled haploid lines from two Indica rice hybrids. Rice Science, 2015, 22(6): 290-299 (doi: 10.1016/j.rsci.2015.07.002).

20. Гончарова Ю.К. Использование метода культуры пыльников в селекции риса. Краснодар, 2012.

21. Ilyushko M.V. Effect of growing conditions of rice donor plants on anther culture in vitro. Journal of Agricultural Science and Technology, 2015, 5: 686-694 (doi: 10.17265/2161$6256 / 2015.08 .007)$. 
22. Chu C. The $\mathrm{N}_{6}$ medium and its applications to anther culture of cereal crops. Proceedings of Symposium on Plant Tissue Culture, 25-30 May 1978, Peking. Science Press, Peking, 1978: 43-50.

23. Илюшко М.В. Сравнительный анализ питательных сред для регенерации растений риса из каллуса в культуре пыльников in vitro. Известия ТСXА, 2017, 2: 126-133.

24. Murashige T., Skoog F. A revised medium for rapid growth and bioassays with tobacco tissue cultures. Physiologia Plantarum, 1962, 15: 473-497 (doi: 10.1111/j.1399-3054.1962.tb08052.x).

25. Першина Л.А., Осадчая Т.С., Бадаева Е.Д., Белан И.А., Россеева Л.П. Изучение особенностей андрогенеза в культуре пыльников сортов и перспективной формы яровой мягкой пшеницы западносибирской селекции, различающихся наличием или отсутствием пшенично-чужеродных транслокаций. Вавиловский журнал генетики и селекции, 2013, 17(1): 40-49.

ФГБНУ Приморский НИИ сельского хозяйства, 692539 Россия, Приморский край, п. Тимирязевский, ул. Воложенина, 30, e-mail: ilyushkoiris@mail.ru $₫$, romashova_1969@mail.ru

Поступила в редакцию 25 сентября 2018 года

Sel'skokhozyaistvennaya biologiya [Agricultural Biology], 2019, V. 54, № 3, pp. 557-565

\title{
SEASONALITY OF ANDROGENETIC RESPONSES IN THE ANTHER CULTURE in vitro IN RICE (Oryza sativa L.)
}

\author{
M.V. Ilyushko, M.V. Romashova
}

Primorskii Research Institute of Agriculture, 30, ul. Volozhenina, pos. Timityazevskii, Primorskii Krai, 692539 Russia, e-mai ilyushkoiris@mail.ru ( $₫$ corresponding author), romashova_1969@mail.ru ORCID:

Ilyushko M.V. orcid.org/0000-0001-7042-8641

The authors declare no conflict of interests

Received September 25, 2018

Romashova M.V. orcid.org/0000-0002-7426-8523

doi: 10.15389 /agrobiology.2019.3.557eng

\section{Abstract}

The conditions for growing donor plants in androgegesis in vitro are considered from the point of view of the influence of physical factors on the plants (illumination, length of daylight, temperature, nutrition of plants). A priori it is believed that any period of the year (season) is suitable for plant tissue culture in vitro, and this is the main advantage of in vitro technologies compared to traditional ones. Seasonality is taken into account only when comparing donor plants grown in the field and under controlled conditions. However, we have not found reports on the study of using procedure of anther in vitro culture throughout the year. This paper is the first to show that, under uniform conditions of donor plants growing, the frequency of callus formation and regeneration of rice (Oryza sativa L.) plants from anthers in vitro culture differs depending on the month (season) when explants were collected. The aim of the studies was to study the seasonal dependence of in vitro androgenetic responses of $O$. sativa when growing donor plants in a climatic chamber conditions. The 5-9 plants of $O$. sativa subsp. japonica Kato, the Cascade variety, were planted monthly during a year and grown in a climatic chamber (at $24{ }^{\circ} \mathrm{C}$ and $21{ }^{\circ} \mathrm{C}, 15000$ lux, $60 \%$ humidity and photoperiod of 14 light/10 dark hours) to be the test anther donors. The anthers from naturally grown plants served as controls. As a result, the seasonal dependence of callus formation in the rice anther culture in vitro was revealed. The peak intensity of callus formation occurs in May and June (15.5-28.3\%). When growing donor plants under artificial conditions at both temperatures, in the best period for anther culture in vitro (May-June) callus formation was higher than in the control. The use of the climatic chamber makes it possible to obtain consistently high values of the intensity of callus formation in some months, which is not always possible in the natural conditions. The temperature of donor plant growing affects the frequency of rice callus formation and the regenerative capacity. The temperature which is lower than optimal for rice plants $\left(21^{\circ} \mathrm{C}\right)$ allows for different frequency of callus formation throughout the year, whereas the rice-comfortable temperature $\left(24{ }^{\circ} \mathrm{C}\right)$ leads to a large seasonal dependence and callus formation from May to September and in December and January. At $21{ }^{\circ} \mathrm{C}$ vs. $24{ }^{\circ} \mathrm{C}$, four times more calluses with green regenerants are formed $(31.6 \%$ vs. $8.8 \%$ ), with an increase in the fraction of doubled haploids up to $28.1 \%$ and their number per callus up to 16.6. A moderate correlation was found between the share of calli with green regenerants and the average number of doubled haploids per callus $(r=0.59$ at $\mathrm{p}=0.05)$. This means that with an increase in the number of calli with green regenerants, which is observed at $21{ }^{\circ} \mathrm{C}$, the total yield of doubled haploids also increases. As to the number of haploids, no such dependence was found. Thus, greenhouses and climatic chambers may serve not only for growing donor plants by researchers, but also for practical use of the most favorable periods for anthers culture technique.

Keywords: Oryza sativa L., androgenesis in vitro, callus formation, regeneration, doubled haploids, seasonality. 